\title{
DEVELOPMENT OF A TRACTOR-TRAILED RICE CLEANING AND MILLING MACHINE
}

\author{
AL-Gezawe A. A. I .*
}

\section{ABSTRACT}

The aims of the present research are to develop and evaluate tractor-trailed rice-milling machine. The factors affecting the performance of the developed milling-machine feeding rate, drum speed, grain moisture-content were studied. The performance measurements were productivity, total machine cleaning efficiency, total grain-losses, power required, specific energy and operational cost. The experimental results reveal that the highest values of productivity and machine efficiency were $1.35 \mathrm{Mg} / \mathrm{h}$ and $97.3 \%$. Meanwhile, the minimum required power and the specific energy were $16.82 \mathrm{~kW}$ and $14.55 \mathrm{kWh} / \mathrm{Mg}$ respectively for tractor-mounted rice milling machine after development, The minimum operating cost was $32.71 \mathrm{~L}$.E/Mg These values were achieved under conditions of feed rate of $1.25 \mathrm{Mg} / \mathrm{h}$, drum speed of 800 rpm and moisture content of $14 \%$.

\section{INTRODUCTION}

7 he rice crop is the most important crop planted in Egypt after wheat. The average of rice-grain productivity per feddan was 4 tons. El-

Raie et al. (1996) studied some mechanical properties of grains such as natural angle of repose, solid friction, hardness, average speeds of grain movement over a flat swing screen. They also studied some aerodynamic properties of grains and straw such as drag coefficient, drag force, terminal velocity, Reynolds number and moisture of grain. They determined the terminal velocity of wheat, rice and barley. They found that the terminal velocity ranged from 5.85 to $9.71 \mathrm{~m} / \mathrm{s}$ for wheat, from 7.89 to $8.55 \mathrm{~m} / \mathrm{s}$ for rice varieties, and 7.49 to $9.95 \mathrm{~m} / \mathrm{s}$ for barley. Koide and Nishiyama (2001) measured the milling power and milling energy during abrasive milling under five rotor revolutions of 800, 1000, 1400, $1600 \mathrm{rpm}$ using a batch type abrasive milling machine. Result indicated that the milling power decreased with milling time.

\footnotetext{
*Researcher of Agric. Res. Inst., Agric. Res. Center, Dokki, Egypt.
} 
Radwan (2001) showed that the mechanical damage occurring in rice grains during the milling process depends not only on the milling machine design but also on the physical properties of rice. Experiments were conducted to study the milling quality and energy consumption for five local rice varieties (Giza-181, Giza-177 and Giza-178, Yasmien and Sakha-102) at different levels of moisture content. The experimental result showed that, grain variety and moisture content had profound effects on energy consumption and grain quality. Sotanabadi and Hemmat (2007) showed that excessive rotation of rice, when the grains revolve inside the milling chamber, increase breakage. Ease of grain movement in the milling chamber could minimize this problem by utilizing screw conveyor at the first part of rotor. In rotor of a conventional milling was equipped with a screw conveyor. The effects of two rotor types (modified and conventional rotors), three output rates of 421,654 and $915 \mathrm{~kg} / \mathrm{h}$ and three blade distances from the agitator 11,12 and $13 \mathrm{~mm}$ were examined on indices of rice quality. Their results showed that only the effect of blade distance on percentage of breakage was significant and the effect of feed rate on all measured parameters was also significant. In addition, the interaction effects of rotor and blade distance, rotor type and feed rate on percentage of whole white rice and breakage were significant respectively. The milling performance index showed that the best condition for both rotors can be obtained at output rate of 421 $\mathrm{kg} / \mathrm{h}$ and 11 or $12 \mathrm{~mm}$ blade distance from the agitator. For this adjustment the average of percentage of breakage in the modified and conventional rotors were 20.5 and 23, respectively. Morad et al (2013), found that the highest values of machine productivity and overall machine efficiency were $1.08,1.17$ and $1.35 \mathrm{Mg} / \mathrm{h}$; and $95.00,95.38$ and $95.66 \%$ for Sakha-101, Giza-171 and Sakha-105 varieties, respectively, while the lowest values of required power and specific energy were 13.0, 13.4 and $13.8 \mathrm{~kW}$; and $17.40,15.68$ and $13.85 \mathrm{~kW} . \mathrm{h} / \mathrm{Mg}$, respectively, for the same rice varieties, furthermore the lowest values of both operational and criterion costs were 8.53, 7.87 and 6.82 L.E./Mg; and 35.96, 31.96 and 29.38 L.E./Mg, respectively, for the same rice varieties. From the experimented 
results, it could be concluded that the optimum operating parameters for the developed milling machine were found at: Drum speed of about $800 \mathrm{rpm}$ for Sakha-101 and 850 rpm for both Giza-171 and Sakha-105 varieties. Grain moisture content of about $14 \%$ for Sakha-101 and $15 \%$ for both Giza-171 and Sakha-105 varieties.

\section{The objectives of this study are to}

- Develop of a rice-grin milling machine.

- Study the effect of some performance factors of developed rice-milling machine such as feeding rate, drum speed and grain moisture-content on machine productivity, cleaning efficiency, grain-losses, power required and specific energy.

- Calculate the operational cost of using the developed rice-grain milling machine.

\section{MATERIALS AND METHOD}

The main experiments were carried out at private farm in Sharkia Governorate.

\subsection{MATERIALS:}

2.1.1.The used crop: was rice crop with variety of Sakha 101 was used.

\subsubsection{Rice Milling Machines:}

\subsubsection{The rice-grain milling machine before modification.}

The rice-grain milling machine before modification consists of the following parts: frame, three hitching points, milling unit (hopper, milling drum, concave) and fixed inclined-sieve. The photograph of the milling machine before modification was shown in Fig. 1.

\subsubsection{The rice-grain milling machine after modification.}

The rice-grain milling machine after modification consists of the following parts:

- Frame: It was made of I-section iron. The total length and width of frame are1500 and $2850 \mathrm{~mm}$ respectively.

- Ground wheels: rubber wheel has diameter of $640 \mathrm{~mm}$ and width of 180 $\mathrm{mm}$. The ground-wheel spacing is $2000 \mathrm{~mm}$. 


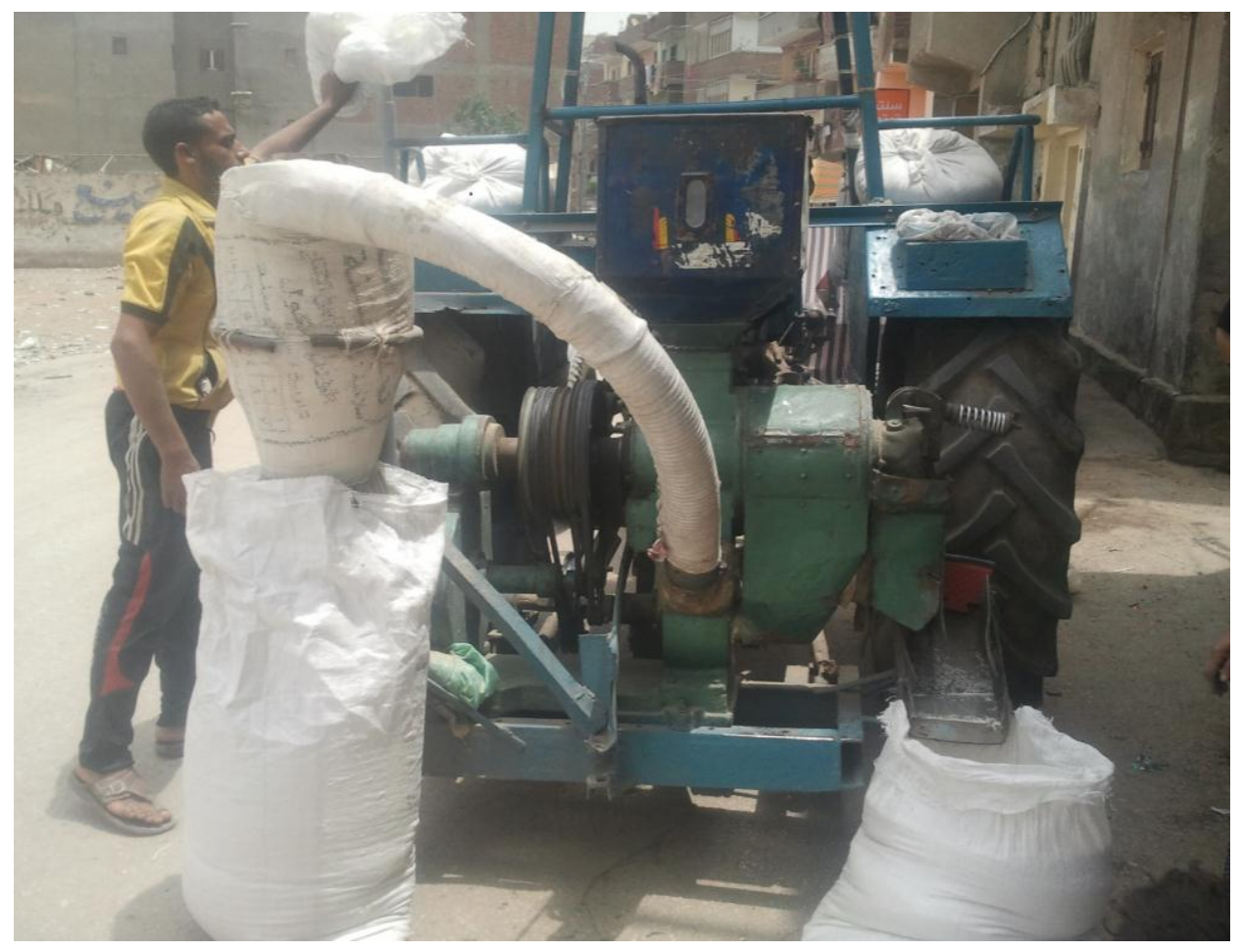

Fig. (1): Rice-grain milling machine before modification.

- Draw- bar pull: made of iron plate with length of $1120 \mathrm{~mm}$, width of 100 $\mathrm{mm}$ and thickness of $100 \mathrm{~mm}$. The edge of pull bar has a hole with diameter of $50 \mathrm{~mm}$.

First paddy rice-grain hopper: was made of sheet steel with $2 \mathrm{~mm}$ thickness. The hopper top has a square shape with dimensions of $500 \times 500$ $\mathrm{mm}$. The hopper bottom has a triangular shape with dimensions of $-240 \mathrm{x}$ 550 x $460 \mathrm{~mm}$ length, width and height respectively. The slope of the hopper side-wall is 45 degree which more than the friction angle between rice grain and hopper wall (29 degree).

-First conveying belt with buckets: a vertical first-belt conveys the rice grain under hopper to the first sieves-unit. The first vertical conveying belt was made of rubber with width of $200 \mathrm{~mm}$, thickness of $10 \mathrm{~mm}$ and length of $3600 \mathrm{~mm}$. The 12 buckets were fixed with the belt by rivets. The buckets spacing is $150 \mathrm{~mm}$. 
-The first sieves-unit: consists of upper and lower sieves. The upper sieve separates the impurities such as plant stems and husks. The lower sieve separates the rice grain on the top and the grass seeds and small soil particles pass through its holes. The grass seeds and small soil clods drop on a solid sieve which exit it from the machine. Reciprocating-speed of the first sievesunit is $335 \mathrm{rpm}$. The upper and lower sieves made of perforated iron-sheet with thickness of $1 \mathrm{~mm}$, length of $1950 \mathrm{~mm}$, width of 600 and height 230 $\mathrm{mm}$. The upper sieve has slutted holes with dimensions of $450 \times 50 \mathrm{~mm}$. The lower sieve has round holes with diameter of $2 \mathrm{~mm}$. The first sieves-unit inclined angle 8 degree.

\section{- Second paddy rice-grain hopper:}

- The paddy rice-grain drops from first sieves-unit to the second hopper. The second hopper was made of sheet steel with $2 \mathrm{~mm}$ thickness. The hopper top has a square shape with dimensions of $400 \times 300 \mathrm{~mm}$. The hopper bottom has a triangular shape with dimensions of $50 \times 310 \times 290 \mathrm{~mm}$. length, width and height respectively. The slope of the hopper side-wall is 45 degree which more than the friction angle between rice grain and hopper wall (29 degree).

- Second conveying belt with buckets: a vertical second-belt conveys the rice grain under from second hopper to the milling-unit. The second vertical conveying belt was made of rubber with width of $200 \mathrm{~mm}$, thickness of 10 $\mathrm{mm}$ and length of $4500 \mathrm{~mm}$. The 15 buckets were fixed with the belt by rivets. The buckets spacing is $150 \mathrm{~mm}$.

- Milling unit: The milling unit was exist in the milling machine before modification. The milling unit consists of the following parts:

(a) Hopper: The paddy rice-grains after cleaning by first sieves units are dropped to the milling-unit hopper by the second conveying-belt. The hopper was made of sheet steel with $2 \mathrm{~mm}$ thickness. The hopper top has a square shape with dimensions of $460 \times 460 \mathrm{~mm}$ and height of $430 \mathrm{~mm}$. The hopper bottom has $150 \mathrm{~mm}$ height with side-wall slope of 45 degree.

(b) Milling drum:

(c) Concave: 
- The second sieves-unit: consists of upper and lower sieves. The upper sieve separates the damage milled grains. The lower solid sieve separates exit the damaged grains from the machine and collected in a container. The upper and lower sieves made of perforated iron-sheet with thickness of 1 $\mathrm{mm}$, length of $1500 \mathrm{~mm}$, width of 500 and height $150 \mathrm{~mm}$. The upper sieve has a holes diameter of $1.5 \mathrm{~mm}$. The second sieves-unit inclined angle 6 degrees.

Reciprocating-speed of the second sieves-unit is $270 \mathrm{rpm}$.

The photograph, isometric and views of the milling machine after modification are shown in Figs. 2, 3, and 4.

\subsubsection{Tractor.}

A four wheel tractor of the standard type was used as a power source

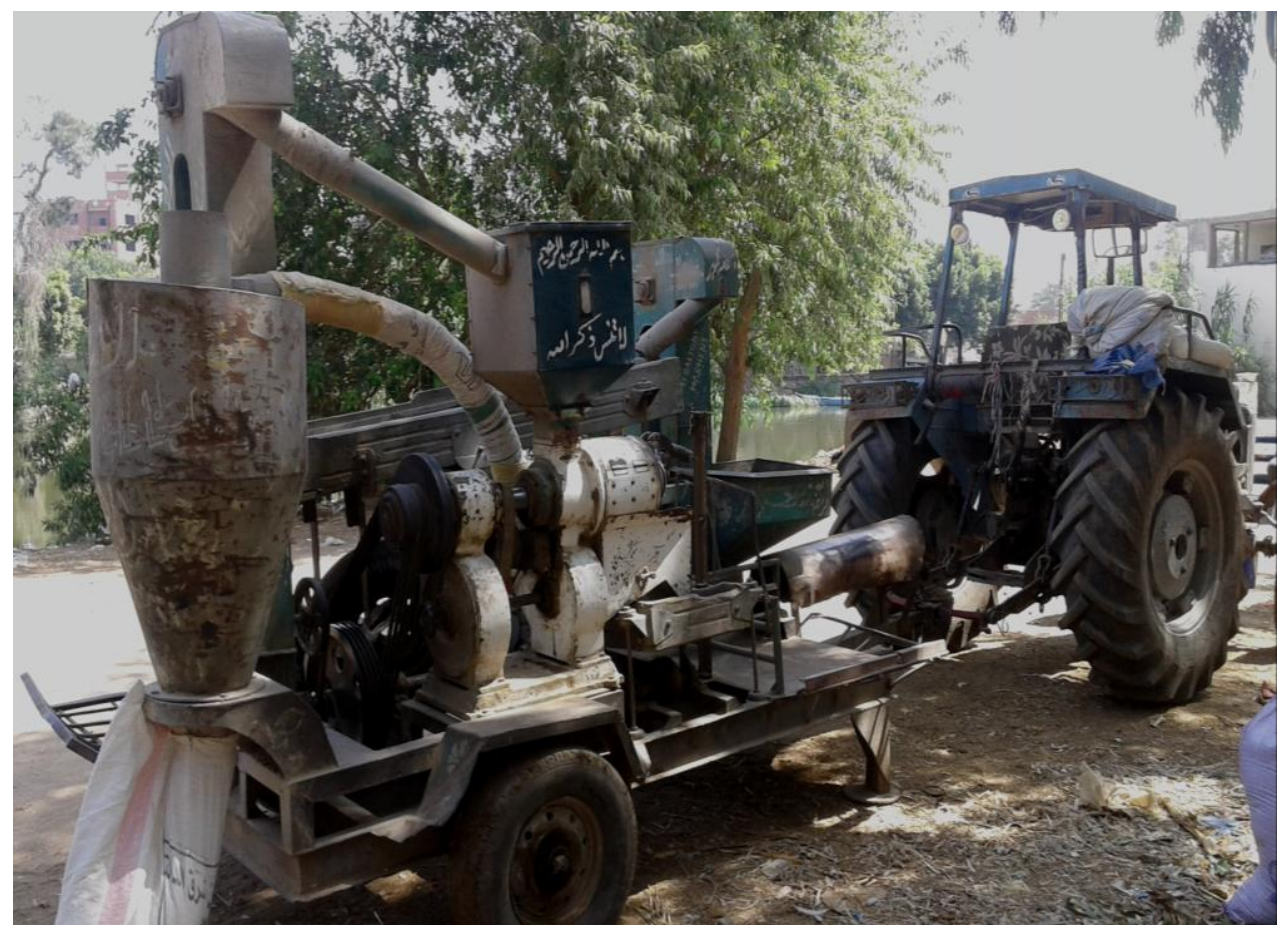

Fig.(2): Tractor-mounted rice milling machine after development. 


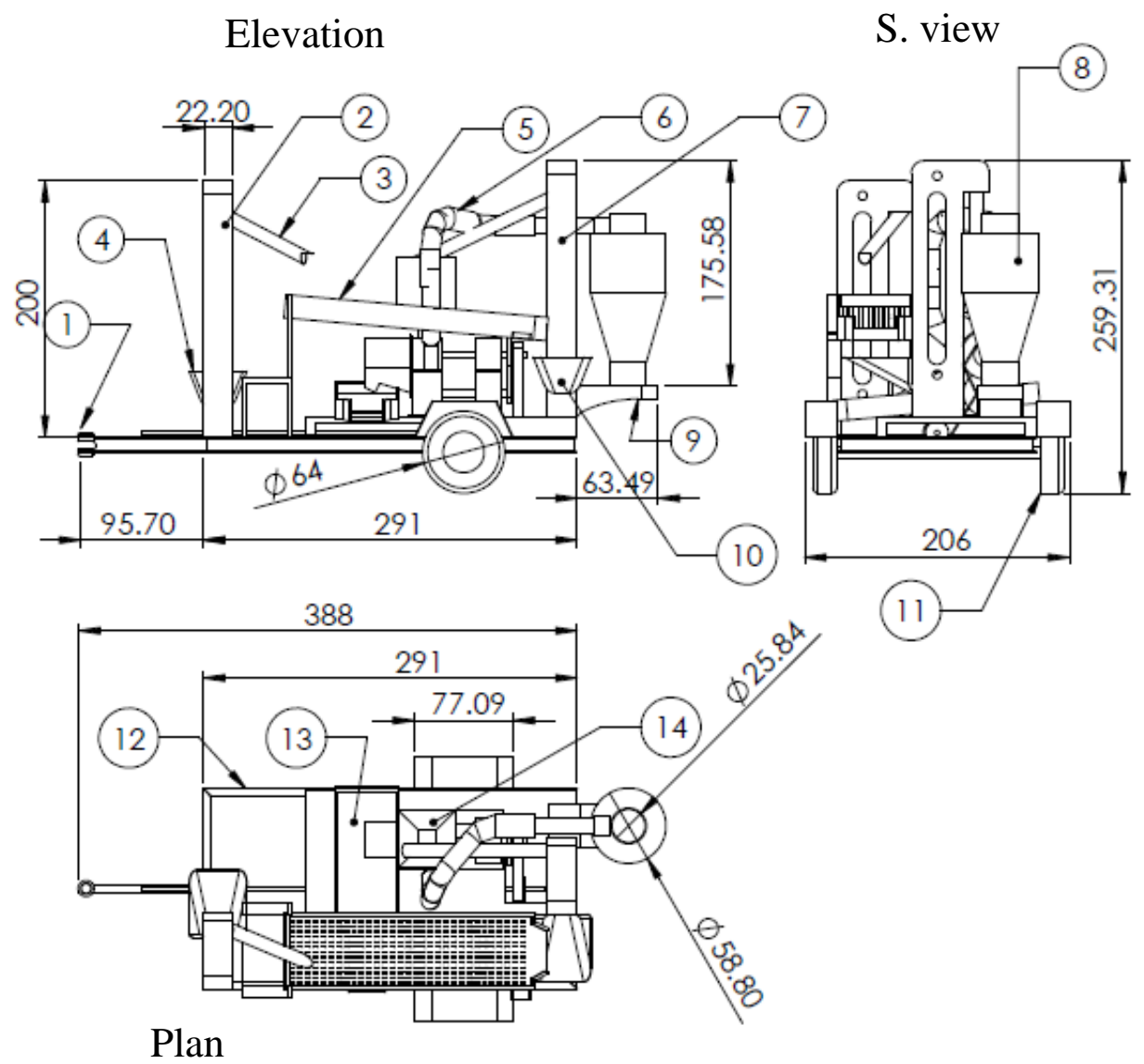

All Dimensions in $\mathrm{cm}$

1-Draw-pull bar.

3-Out let of grain.

5-First sieves-unit.
2- First conveying belt with buckets.

4- First paddy rice-grain hopper.

6-Conveying tube.

7- Second conveying belt with buckets. 8-Bran turning hopper.

9- Bran out let.

11-Ground wheel.

13- Second sieves-unit.
10- Second paddy rice-grain hopper. 12- Frame.

14- Milling-unit hopper.

Fig.(3) : The three Views of the tractor-mounted rice milling machine after development 


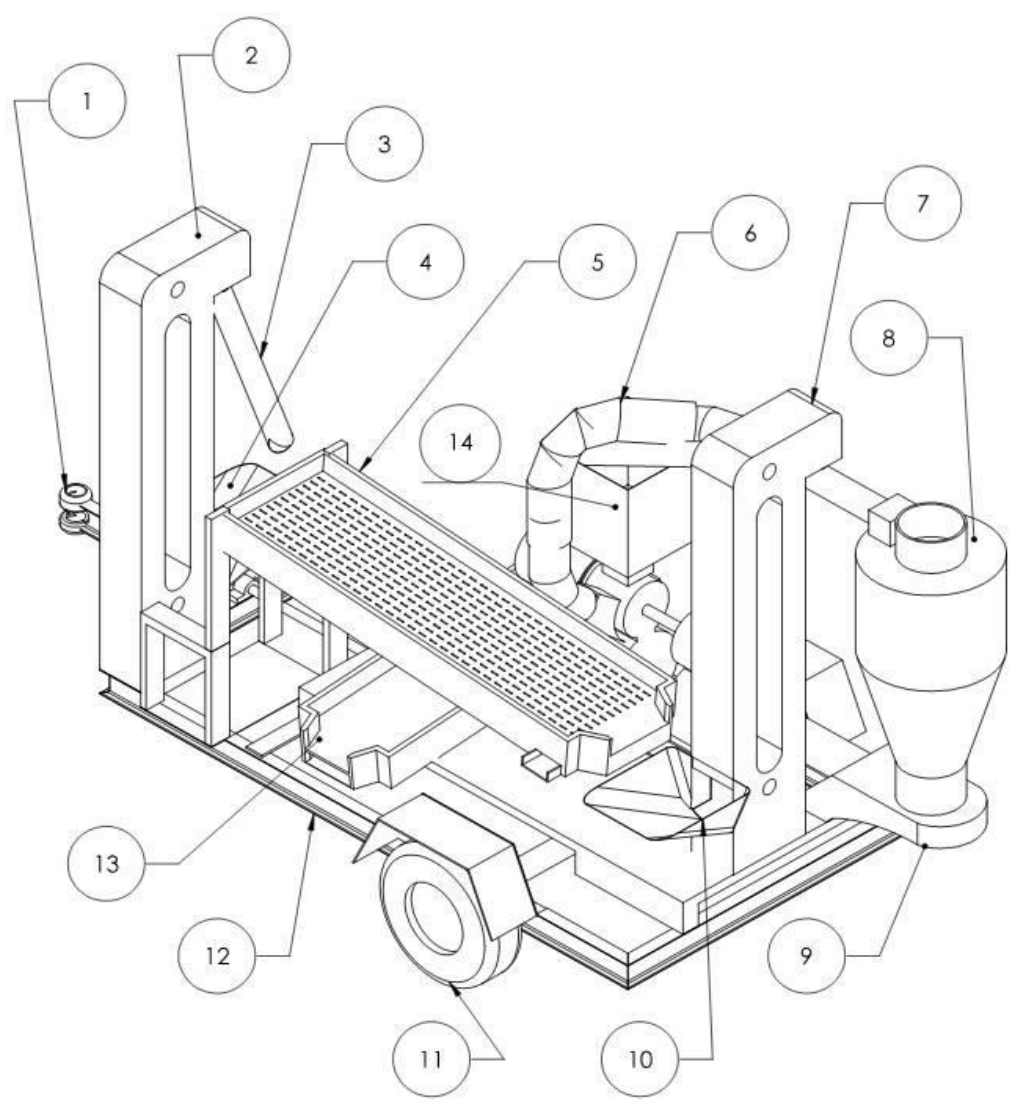

1-Draw-pull bar.

3-Out let of grain.

5-First sieves-unit.

7- Second conveying belt with buckets.

9- Bran out let.

11-Ground wheel.

13- Second sieves-unit.
2- First conveying belt with buckets.

4- First paddy rice-grain hopper.

6-Conveying tube.

8-Bran turning hopper.

10- Second paddy rice-grain hopper.

12- Frame

14- Milling-unit hopper.

Fig.(4):Isometric of the tractor-mounted rice milling machine after development

with the following specifications: model Naser 65, Engine type diesel, 4 cylinders, Power at rated speed $65 \mathrm{hp}(48 \mathrm{KW})$ P.T.O revolution, rpm 540-1000 and Mass $2250(\mathrm{Kg})$. was used to operate the developed milling machine. 


\subsection{METHODS:}

\subsubsection{Experimental conditions:}

Experiments were conducted under multi variables: four grain moisture contents $(20,18,16$ and $14 \%)$ - four feeding rates $(1,1.25,1.5$ and 1.75 $\mathrm{Mg})$ and four drum speeds $(650,800,950$ and $1050 \mathrm{rpm})$ for tractormounted rice milling machine after development.

\subsection{MEASUREMENTS:}

Evaluation of the performance of the used developed rice milling machine was based on the following indicators:

\section{-Total grain losses:}

Total grain losses includes both unshelled grain losses and broken grain losses. The percentage of total grain losses was calculated using the following equation:

Totalgrain losses $=$ unshelled grain losses + broken grain losses

The percentage of unshelled grains $\left(\mathrm{Unsh}_{\mathrm{g}}\right)$ :

$$
\text { Unsh }_{\mathrm{g}}=\frac{\text { Mass of unshulled rice grains in thesample }}{\text { Totalmass of thesample }} \times 100
$$

-The percentage of broken grains (Bg):

$$
\mathrm{Bg}=\frac{\text { Mass of broken rice grains in thesample }}{\text { Totalmass of thesample }} \times 100
$$

-Machine efficiency (Me):

Machine efficiency was calculated using the following equation:

$$
\mathrm{Me}=\frac{\text { Output grain mass frommilling operationin thesample }}{\text { Totalmass of thesample }} \times 100
$$

\section{-Machine productivity:}

Machine productivity was determined by the following equation:

$$
\mathbf{M p}=\frac{\mathrm{Ms}}{\mathrm{t}}, \mathrm{Mg} / \mathrm{h}
$$

Where: $\mathrm{Mp}=$ machine productivity, $\mathrm{Mg} / \mathrm{h}$.

$$
\begin{aligned}
\mathrm{Ms} & =\text { mass of sample, } \mathrm{Mg} . \\
\mathrm{t} & =\text { time consumed in the milling operation, } \mathrm{h} .
\end{aligned}
$$

\section{- Cleaning efficiency.}

cleaning efficiency was calculated by the following: 
Cleaning efficiency, $\%=\frac{M-M c}{M} \times 100$

Where: $\mathrm{M}=$ Mass of sample before cleaning, $\mathrm{g}$

$\mathrm{Mc}=$ Mass of sample after cleaning, $\mathrm{g}$

\section{- Fuel consumption}

Fuel consumption per unit time was determined by using a calibrated tank (Refilling method) to measure the volume of fuel consumed during the operation time.

\section{- Required power}

The following formula was used to estimate the required power. (Hunt, 1983).

$\mathrm{RP}=\left[\mathrm{f} . \mathrm{c}(1 / 3600) \mathrm{PE} \times \mathrm{L} . \mathrm{C} . \mathrm{V} \times 427 \times \eta_{\text {thb }} \times \eta_{\mathrm{m}} \times 1 / 75 \times 1 / 1.36\right], \mathrm{kW}$

Solving equation the consumed energy can be calculated as following: $\mathrm{RP}($ Diesel $)=3.16$ f.c. , $\mathrm{kW}$

Where: $\mathrm{f} . \mathrm{c}=$ The fuel consumption, $(\mathrm{l} / \mathrm{h})$.

$\mathrm{PE}=$ The density of fuel, $(\mathrm{kg} / \mathrm{l})$, (for Diesel $=0.85)$.

L.C.V = The lower calorific value of fuel, $(11.000 \mathrm{k.cal} / \mathrm{kg})$.

$\eta_{\text {thb }}=$ Thermal efficiency of the engine (35\% for Diesel).

$427=$ Thermo-mechanical equivalent, $(\mathrm{kg} \cdot \mathrm{m} / \mathrm{k} . \mathrm{cal})$.

$\eta_{\mathrm{m}}=$ Mechanical efficiency of the engine ( $80 \%$ for Diesel).

-Specific energy:

Specific energy for the milling operation can be calculated as follows: Specific energy $=\frac{\text { Required power }}{\text { Machine productivity }}, \mathrm{kW} \cdot \mathrm{h} / \mathrm{Mg}$

\section{-Criterion cost:}

The criterion cost required for the threshing and cleaning operation was estimated using the following equation (Awady, 1982): Criterioncost $=$ operatingcost + grain losses cost,L.E. $/ \mathrm{Mg}$

\section{-Operational cost:}

The operational cost was determined from the following formula:

Operatingcost $=\frac{\text { Machine cost }}{\text { Machine productivity }}, \mathrm{L} \cdot \mathrm{E} / \mathrm{Mg}$

The machine cost is determined by using the fixed and variable costs calculation. 


\section{RESULTS AND DISCUSSION}

The obtained results will be discussed under the following items.

\section{1: Effect of different operating parameters on the productivity of the developed rice milling machine.}

Representative values of machine productivity versus feed rate, drum speed and grain moisture content were illustrated in Fig.(5) Concerning to the effect of feed rate on the machine productivity. Increasing feed rate from 1.0 to $1.75 \mathrm{Mg} / \mathrm{h}$, machine productivity increased from 0.775 to $1.25 \mathrm{Mg} / \mathrm{h}$ at constant drum speed of $800 \mathrm{rpm}$, and constant moisture content of $14 \%$.

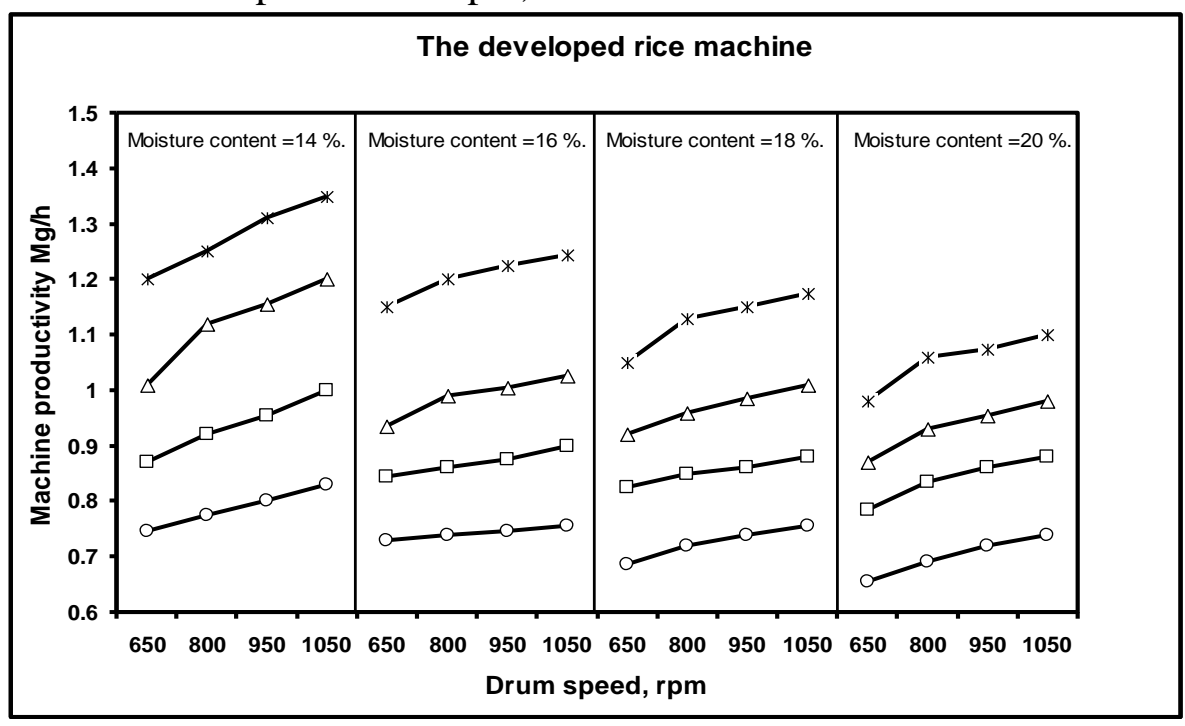

Feeding rate: $(\mathrm{Mg} / \mathrm{h}) \multimap 0-1.00 \multimap \square-1.25 \multimap-1.50 \rightarrow 1.75$

Fig.(5): Effect of different operating parameters on the productivity of the developed rice milling machine.

Regarding the effect of drum speed on machine productivity increasing drum speed from 650 to $1050 \mathrm{rpm}$, machine productivity increased from 0.870 to $1.00 \mathrm{Mg} / \mathrm{h}$ at constant feed rate of $1.25 \mathrm{Mg} / \mathrm{h}$ and grain moisture content of $14 \%$. Concerning the effect of grain moisture content on machines productivity, increasing grain moisture content from 14 to $20 \%$, the machines productivity decreased from 0.920 to $0.835 \mathrm{Mg} / \mathrm{h}$ at constant feed rate of $1.25 \mathrm{Mg} / \mathrm{h}$ and constant drum speed of $800 \mathrm{rpm}$. The machine productivity increased by increasing grain moisture content is due to the increase in weight of grains. 


\subsection{Effect of different operating parameters on efficiency of the}

\section{developed rice milling machine.}

Representative values of machine efficiency versus feed rate, drum speed and grain moisture content were presented in Fig.(6) Concerning the effect of feed rate on overall machine efficiency, increasing feed rate from 1.00 to $1.25 \mathrm{Mg} / \mathrm{h}$ the machine efficiency increased from 96.90 to $97.30 \%$, .

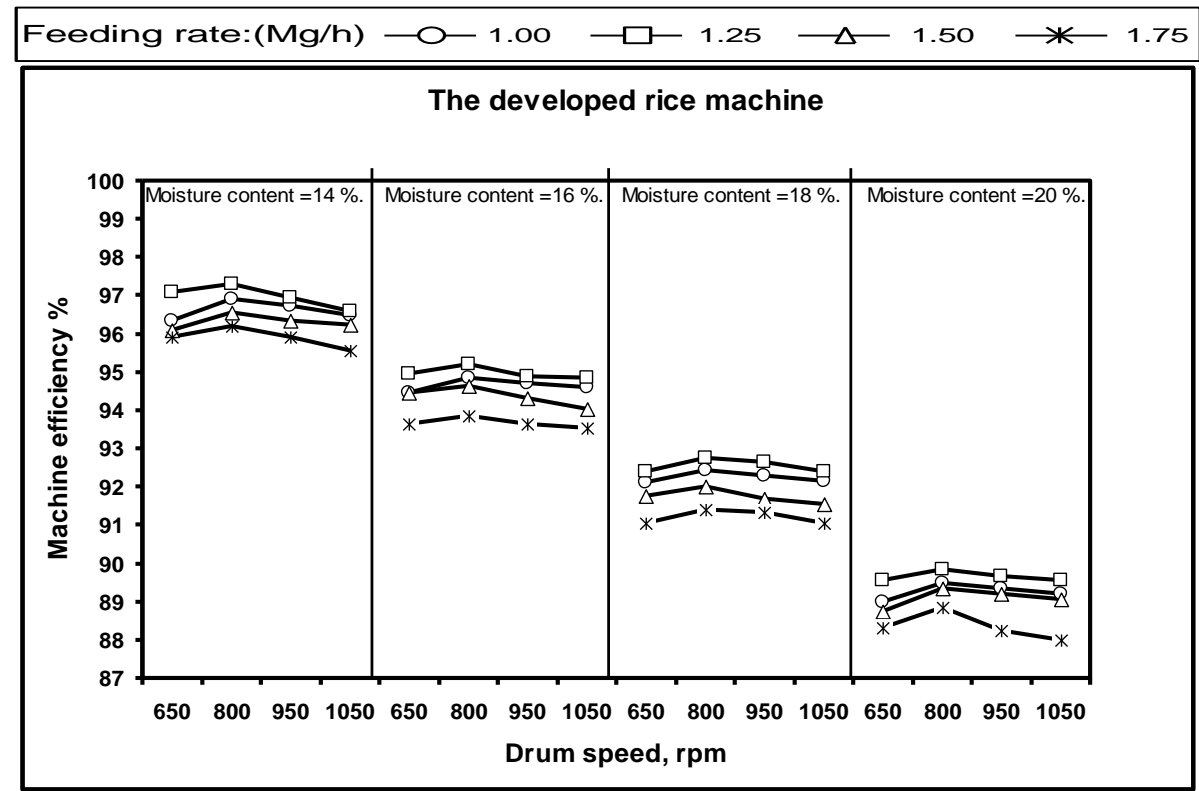

Fig.(6): Effect of different operating parameters on the efficiency of the developed rice milling machine

Any further increase in feed rate more than $1.25 \mathrm{up}$ to $1.75 \mathrm{Mg} / \mathrm{h}$ decreased machine efficiency from 97.30 to $96.20 \%$ at constant drum speed of 800 rpm and grain moisture content of $14 \%$. Regarding the effect of drum speed on machine efficiency, increasing drum speed from 650 to $800 \mathrm{rpm}$ the overall machine efficiency increased from 97.10 to $97.30 \%$, . Any further increase in drum speed more than 800 up to1050 rpm decreased machine efficiency from 97.30 to $96.60 \%$ at constant feed rate of $1.25 \mathrm{Mg} / \mathrm{h}$ and grain moisture content of $14 \%$. The increase in machine efficiency in the range from 650 to $800 \mathrm{rpm}$ is attributed to the high stripping and impacting forces applied to the grains, that tend to improve milling operation. While the vise versa is noticed in the range from 800 to $1050 \mathrm{rpm}$ due to the increase in grain losses. 
Concerning the effect of grain moisture content on machine efficiency, increasing grain moisture content from 14 up to $20 \%$ decreased machine efficiency from 97.30 to $89.85 \%$ at constant drum speed of $800 \mathrm{rpm}$ and feed rate of $1.25 \mathrm{Mg} / \mathrm{h}$ at the same previous conditions. Values of grain moisture content more or less than the optimum value tend to decrease machine efficiency because of increasing the total grain losses.

\subsection{Effect of different operating parameters on the cleaning efficiency} of the developed rice milling machine.

From the pre experiments, in materials and method chapter and also the optimum sieve speed for the rice grains, sieve speed cleaning final for the rice and sieve inclination were determined and adjusted at $350 \mathrm{rpm}, 270 \mathrm{rpm}$ and $10 \mathrm{deg}$, respectively to be suitable for operating the cleaning unit attached with the rice milling machine to maximize its efficiency and rice quality. Representative values of machine cleaning efficiency versus feed rate, drum speed and grain moisture content are represented in Fig.(7) Concerning the effect of feed rate on cleaning efficiency, increasing feed rate from 1.00 to $1.25 \mathrm{Mg} / \mathrm{h}$, the cleaning efficiency increased from 97.40 to $98.05 \%$, . Any further increase in feed rate more than 1.25 up to $1.75 \mathrm{Mg} / \mathrm{h}$ decreased cleaning efficiency from 98.05 to $97.35 \%$ at constant drum speed of $800 \mathrm{rpm}$ and grain moisture content of $14 \%$.

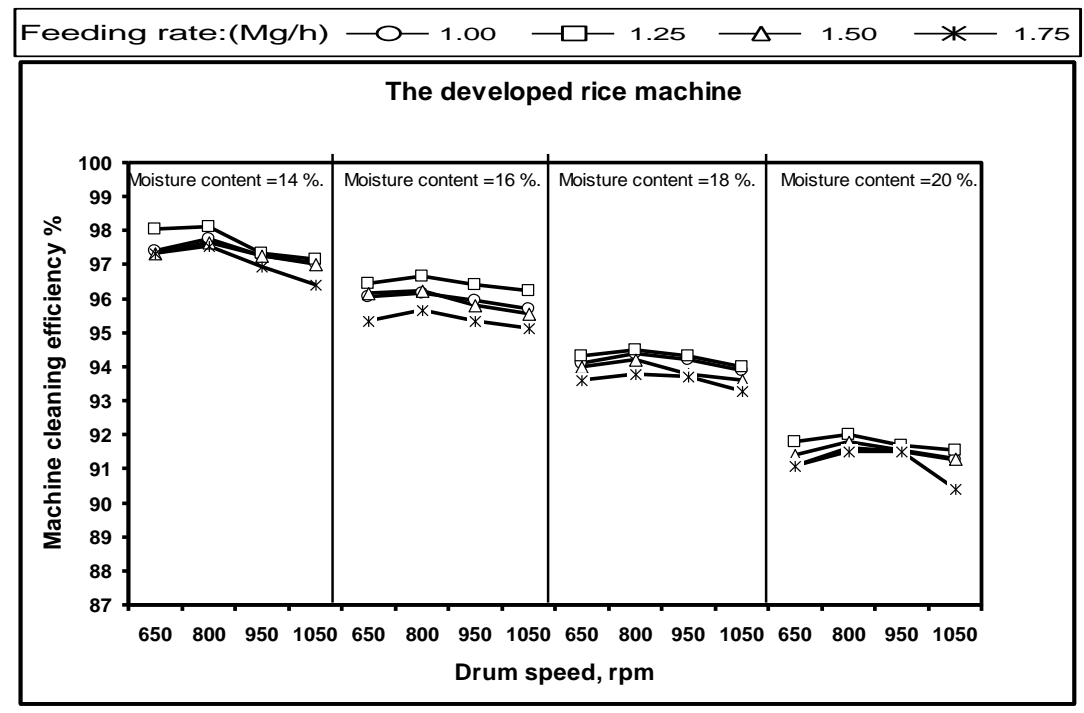

Fig.(7): Effect of different operating parameters on the cleaning efficiency of the developed rice milling machine.

Regarding the effect of drum speed on cleaning efficiency, increasing drum speed from 650 to $800 \mathrm{rpm}$ the machine cleaning efficiency increased from 
97.40 to $97.75 \%$, . Any further increase in drum speed more than 800 up to $1050 \mathrm{rpm}$ decreased cleaning efficiency from 97.40 to $97.05 \%$ at constant feed rate of $1.25 \mathrm{Mg} / \mathrm{h}$ and grain moisture content of $14 \%$.

The increase in the efficiency of the cleaning device in the range of 650-800 $\mathrm{rpm}$ at feeding rate of $1.25 \mathrm{Mg} / \mathrm{h}$ and moisture content of $14 \%$ which were considered the most appropriate factors with a sieve grain main speed due to the disposal of a greater amount of impurities present with the grain as well as the disposal of a greater amount of broken grain through a sieve final cleaning of the rice grains after the milling process and vice versa at high speeds of 800-1050 rpm, due to the increase in grain losses.

Concerning the effect of grain moisture content on cleaning efficiency, increasing grain moisture content from 14 up to $20 \%$, decreased cleaning efficiency from 98.10 to $92.00 \%$ at constant drum speed of $800 \mathrm{rpm}$ and feed rate of $1.25 \mathrm{Mg} / \mathrm{h}$, at the same previous conditions. This is due to the high moisture content of grain impurities stick and are difficult to be separated as well as increasing broken grain at high- drum speed.

\subsection{Effect of different operating parameters on total grain losses of the developed rice milling machine.}

Representative values of unshelled grains, broken grains and total grains losses versus feed rate, drum speed and grain moisture content are illustrated in Fig.(8).

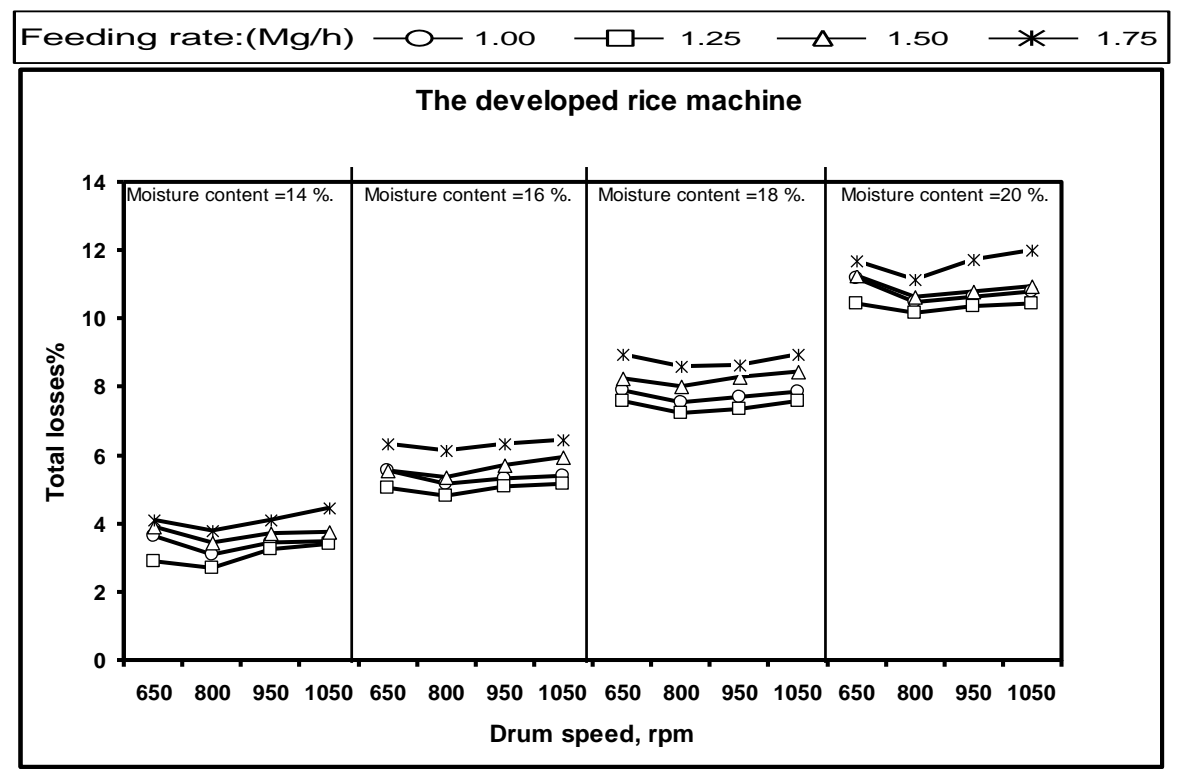

Fig.(8): Effect of different operating parameters on total grain losses of the developed rice milling machine. 
Concerning the effect of feed rate on the total grain losses, increasing feed rate from 1.0 to $1.25 \mathrm{Mg} / \mathrm{h}$, the total grain losses decreased from 3.10 to $2.70 \%$. Any further increase in feed rate more than 1.25 up to $1.75 \mathrm{Mg} / \mathrm{h}$ increased total grain losses from 2.70 to $3.80 \%$ at constant drum speed of $800 \mathrm{rpm}$ and grain moisture content of $14 \%$. Increasing feed rate led to increase unshelled grains due the excessive

grains in the milling unit, consequently the material leave the device without adequate milling that tends to increase unshelled grains. So, the total grain losses including both broken grains and unshelled grains are essential to establish optimum working conditions. Relating to the effect of drum speed on the total grain losses, Fig.(8) shows that, increasing drum speed from 650 to $800 \mathrm{rpm}$, the total grain losses decreased from 2.90 to $2.70 \%$.

Any further increase in drum speed more than 800 up to $1050 \mathrm{rpm}$ increased total grain losses from 2.70 to $3.40 \%$ at constant feed rate of $1.25 \mathrm{Mg} / \mathrm{h}$ and grain moisture content of $14 \%$. The increase in broken grains by increasing drum speed is due to the high impacting force applied to the grains by the drum slices. While the decrease in unshelled grains by increasing drum speed is attributed to the high stripping and impacting forces applied to the grains, that tended to improve milling operation and decrease unshelled grains. With respect to the effect of grain moisture content on the total grain losses, results in Fig.(8) show that, increasing grain moisture content from 14 to $16 \%$ the total grain losses increased from 2.70 to $4.80 \%$. Any further increase in grain moisture content more than 14 up to $20 \%$ increased total grain losses from 2.70 to $10.15 \%$ at constant drum speed of $800 \mathrm{rpm}$ and feed rate of $1.25 \mathrm{Mg} / \mathrm{h}$. Higher values of grain moisture content more than the optimum value $2.70 \%$, tend to increase the total losses because of increasing unshelled grains by increasing grain moisture content. On the other side, the lower values of grain moisture content less than the optimum value 2.70 , tend to increase total grain losses due to the increase in broken grains by decreasing grain moisture content.

3.5 Effect of different operating parameters on required power of the developed rice milling machine.

Values of both required power and specific energy versus feed rate, drum speed and grain moisture content are represented in Fig.(9) and Fig.(10) Relating to the effect of feed rate on required power and specific energy, 
increasing feed rate from 1.00 to $1.75 \mathrm{Mg} / \mathrm{h}$, the required power increased from 16.82 to $18.62 \mathrm{~kW}$, while the specific energy decreased from 21.70 to $14.55 \mathrm{~kW} . \mathrm{h} / \mathrm{Mg}$, at constant drum speed $800 \mathrm{rpm}$ and grain moisture content of $14 \%$. As to the effect of drum speed on required power and specific energy, increasing drum speed from 650 to $1050 \mathrm{rpm}$, the required power increased from 17.10 to $18.30 \mathrm{~kW}$, while the specific energy decreased from 19.65 to18.30 kW.h/Mg, at constant feed rate of $1.25 \mathrm{Mg} / \mathrm{h}$ and grain moisture content of $14 \%$.

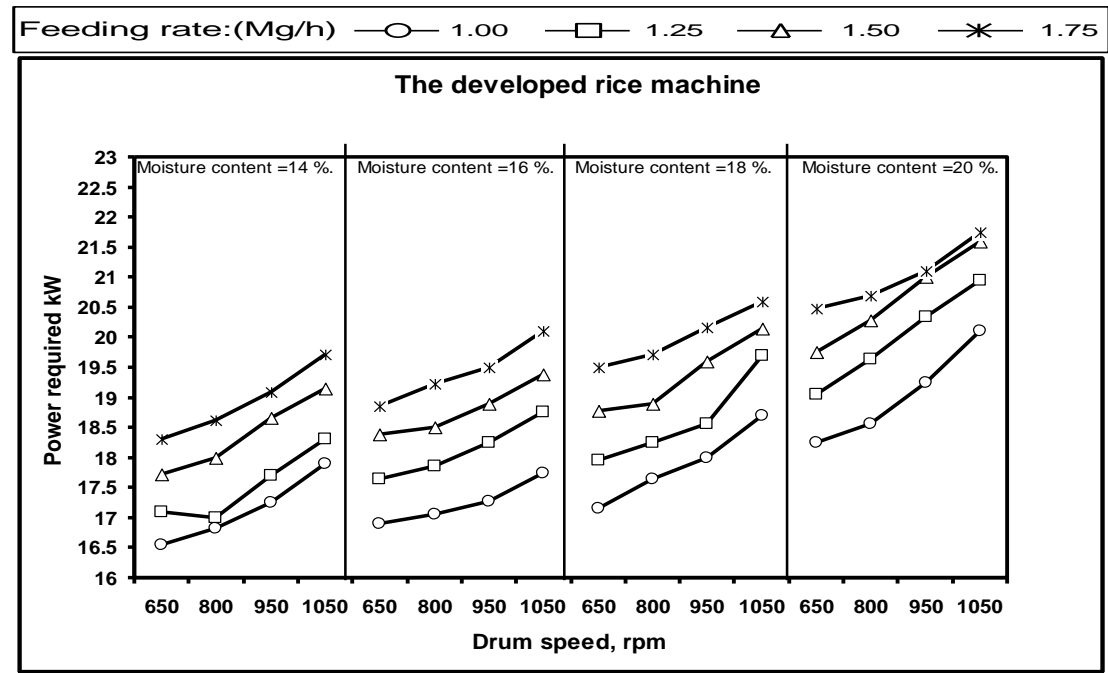

Fig.(9): Effect of different operating parameters on required power of the developed rice milling machine.

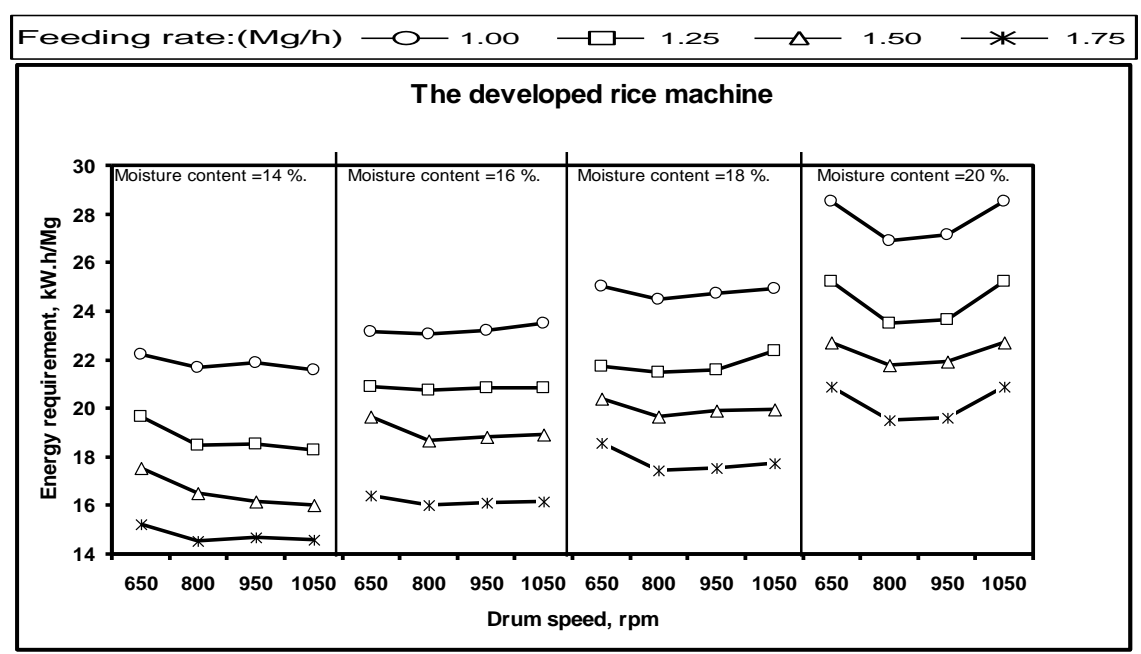

Fig.(10):Effect of different operating parameters on energy requirement of the developed rice milling machine. 
Power increased by increasing drum speed mainly because the increase in drum speed is frequently accompanied by appreciable increase in fuel consumption, that tends to increase required power. In relation to the effect of grain moisture content on required power and specific energy, obtained results show that increasing grain moisture content from 14 to $20 \%$, the required power increased from 17.00 to $19.63 \mathrm{~kW}$, while the specific energy increased from 18.47 to $23.50 \mathrm{~kW} . \mathrm{h} / \mathrm{Mg}$, at constant drum speed of $800 \mathrm{rpm}$ and feed rate of $1.25 \mathrm{Mg} / \mathrm{h}$. The increase in both power and specific energy by increasing grain moisture content is attributed to the excessive load of grains on the machine devices which consumed more energy.

\subsection{Effect of different operating parameters on operational and criterion}

\section{cost of the developed rice milling machine.}

A complete cost analysis was made at different operating conditions and related with machine productivity. The resulting operating cost was found to be affected by both feed rate and power.

Representative values of criterion cost versus feed rate, drum speed and grain moisture content are present in Fig.(11) and Fig.(12)The criterion cost was the sum of operational cost and grain losses cost. Concerning to the effect of feed rate on the criterion cost, increasing feed rate from 1.00 to $1.25 \mathrm{Mg} / \mathrm{h}$ the criterion cost decreased from 38.83 to $32.71 \mathrm{~L} . \mathrm{E} / \mathrm{Mg}$.

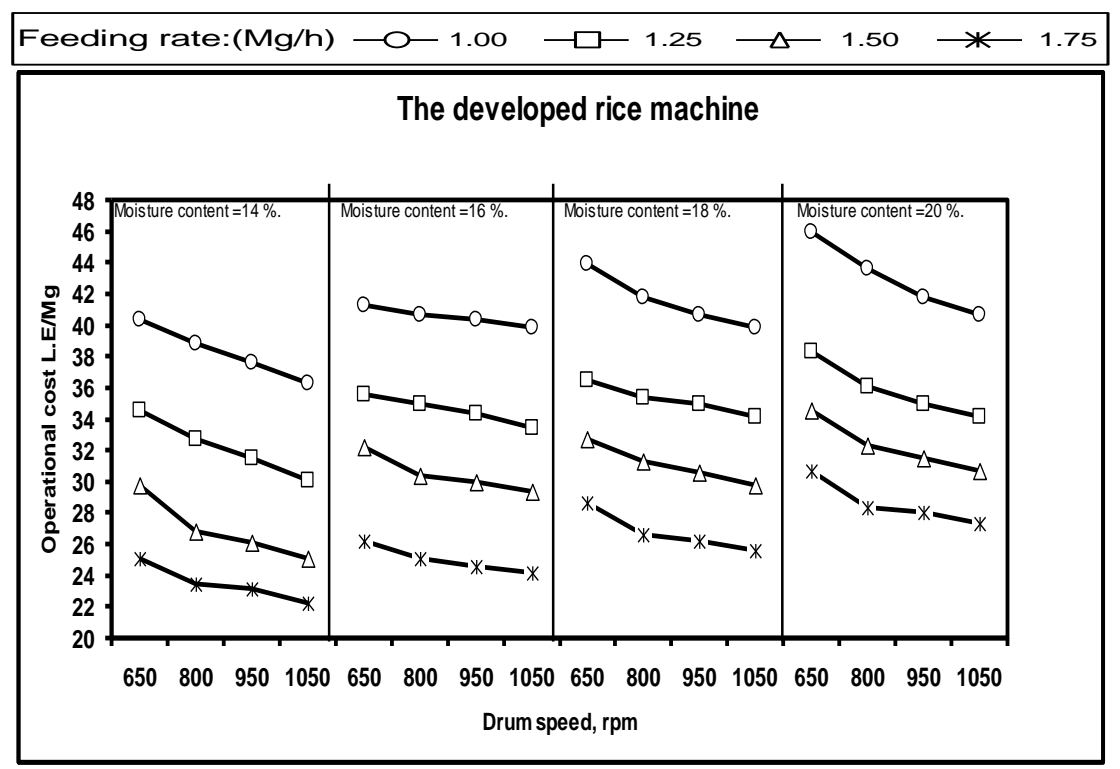

Fig.(11): Effect of different operating parameters on operational cost of the developed rice milling machine. 


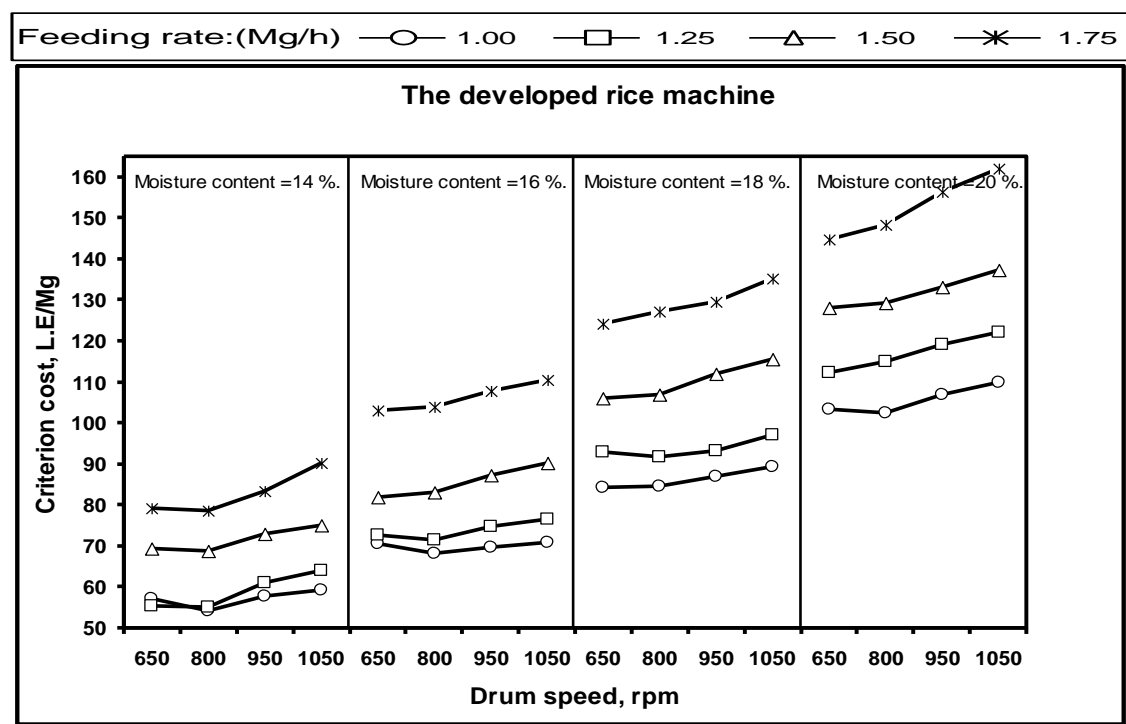

\section{Fig.(12): Effect of different operating parameters on criterion cost of the developed rice milling machine.}

Any further increase in feed rate more than 1.25 up to $1.75 \mathrm{Mg} / \mathrm{h}$ increased criterion cost from 32.71 to $78.74 \mathrm{~L} . \mathrm{E} / \mathrm{Mg}$, at constant drum speed of 800 rpm and grain moisture content of $14 \%$. Relating to the effect of drum speed on the criterion cost, increasing drum speed from 650 to $800 \mathrm{rpm}$ the criterion cost decreased from 57.29 .75 to $54.94 \mathrm{~L} . \mathrm{E} / \mathrm{Mg}$. Any further increase in drum speed more than 800 up to $1050 \mathrm{rpm}$ increased criterion cost from 54.94 to $64.10 \mathrm{~L} . \mathrm{E} / \mathrm{Mg}$ at constant feed rate of $1.25 \mathrm{Mg} / \mathrm{h}$ and grain moisture content of $14 \%$.

With Regard to the effect of grain moisture content on the criterion cost, increasing grain moisture content from 14 to $20 \%$ the criterion cost increased from 54.94 to 114.85 L.E/Mg.

Both higher and lower values of drum speed, feed rate and grain moisture content more or less than the optimum value tend to increase criterion cost due to the increase in total grain losses.

\section{CONCLUSION}

- From the obtained results, the following conclusions can be taken: The highest values of machine productivity and machine efficiency were $1.350 \mathrm{Mg} / \mathrm{h}$; and $97.30 \%$,respectively.

- The highest values of machine cleaning efficiency were $98.05 \%$,was achieved under speeds of sieve cleaning primary, sieve cleaning final, and drum speeds 335,270 , and $800 \mathrm{rpm}$ respectively. 
- The lowest values of required power and specific energy, were16.54 $\mathrm{kW}$; and $14.60 \mathrm{~kW} . \mathrm{h} / \mathrm{Mg}$, under conditions of feed rate of $1.25 \mathrm{Mg} / \mathrm{h}$, drum speed of $800 \mathrm{rpm}$ and moisture content of $14 \%$.

- The lowest values of both operational and criterion costs were 22.29 L.E./Mg; and 90.17 L.E./Mg, under conditions of feed rate of $1.25 \mathrm{Mg} / \mathrm{h}$, drum speed of $800 \mathrm{rpm}$ and moisture content of $14 \%$.

\section{REFERENCES}

Awady, M. N; E. Y. Ghoniem, and A. I. Hashish (1982): Agriculture comparison between wheat combine harvesters under Egyptian conditions. Res. Bul. Ain-Shams Univ.:13p.

El-Raie, A. E. S; N. A. Hendawy and A.Z. Taib (1996). Study of physical and engineering properties for some agricultural products. Misr. J. Ag. Eng., 13 (1):211- 226.

Hunt, D. (1983): Farm power and machinery management. $8^{\text {th }}$ Ed. Iowa state Univ., Press Ames, USA. Ames, Iowa, USA: 364-368.

Koide, S. and Y. Nishiyama (2001): Studies on abrasive rice milling (part2) Milling power model and milling energy model. Journal of the Japanese Society of Agricultural Machinery,63 (6) 63-67

Morad, M. M; M. M. Badr, M. M. A. EL- sharabasy and E. I. Abdel - Aal (2013): Development of rice milling machine for different rice varieties to improve product quality. M. J. Ag. Eng. 30 (3): 599- 626.

Radwan, S. M. (2001): The potential energy consumption for milling some Egyptian rice varieties. Misr J. Ag. Eng., 18(3): 537-551.

Soltanabadi, M. H. and A. Hemmat (2007): Effect of blade distance and output rate on rice quality in a modified blade-type milling machine. Journal of Science and Technology of Agriculture and Natural Resources,11(1A):135-146.

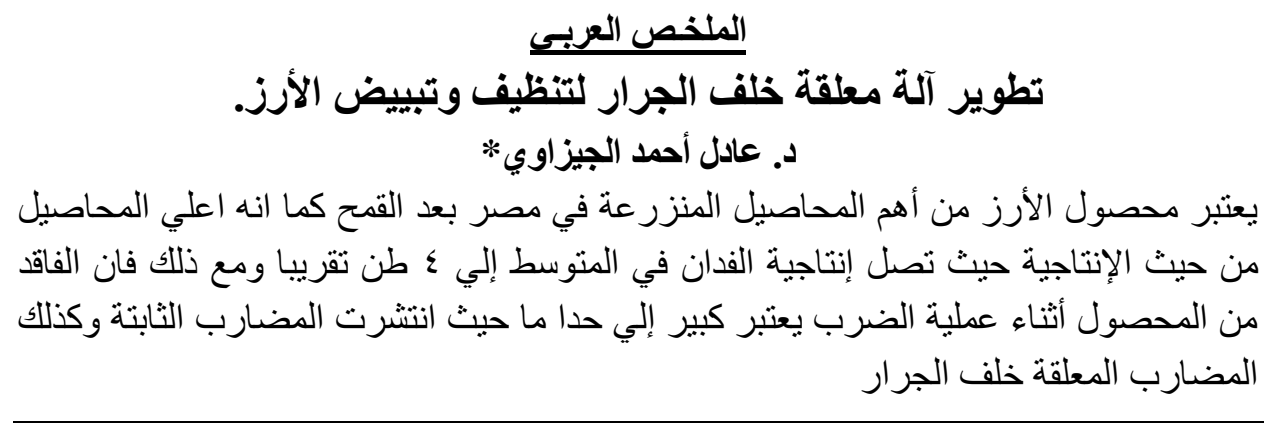

باحث ـ معهة بحوث الهندة الزراعية ـ مركز البحوث الزراعية مصر. 


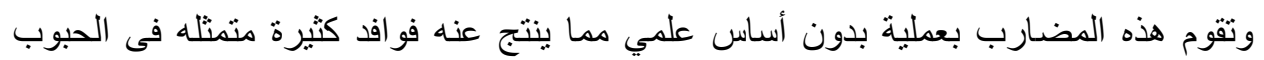
المكسورة والحبوب غبر المقتورة وبالتالي تقل القيمة النقدية للمنتج من الأرز الأبيض. وكان من أهداف هذه الدراسة:

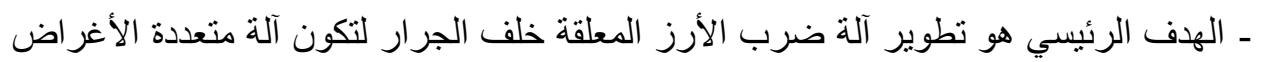

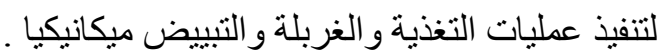

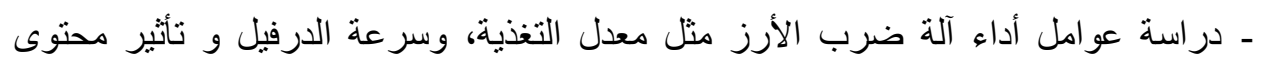

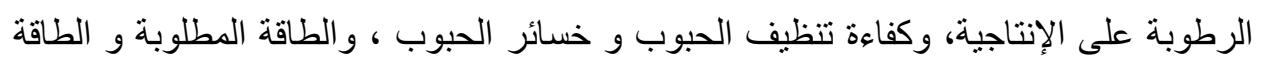

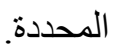
ـ ـ در اسة تكاليف التشغيل لآلة ضرب الأرز.

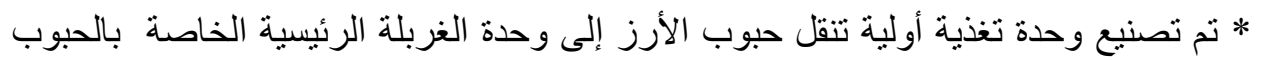

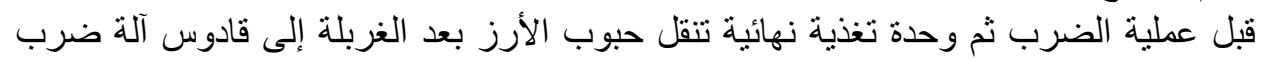

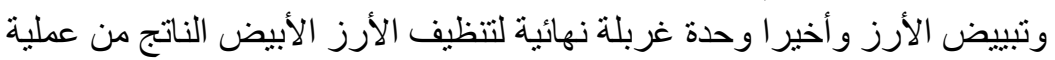

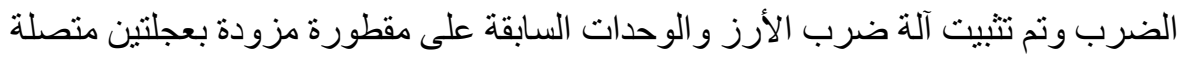
بالجرار ـ ومصدر القدرة لهذه الآلة هو عمود الإدارة الخلفي للجرار (جرار نصر

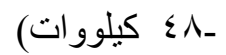

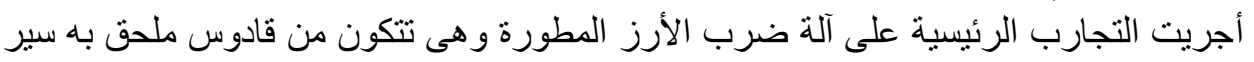

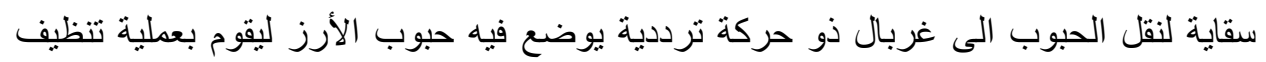

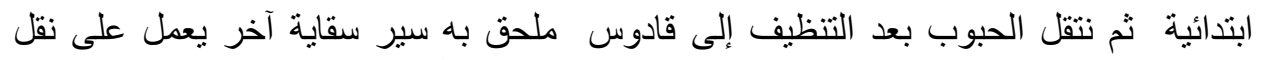

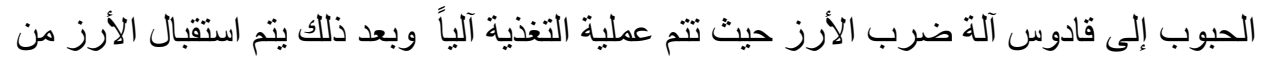

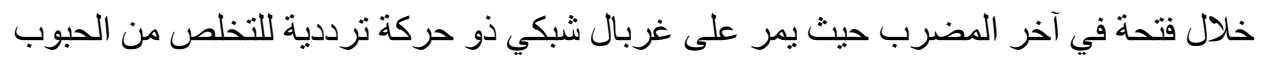

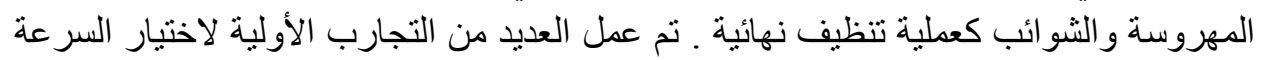

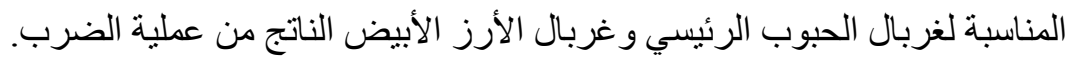

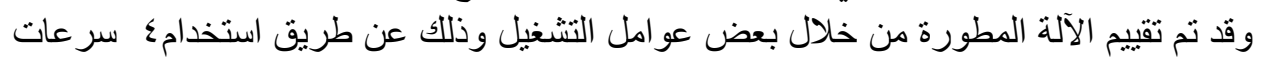

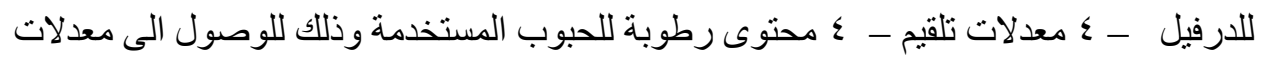
التشغيل المثلى مما يعطى اعلى جودة و أقل تكلفة ولفيل وربحية عالية.

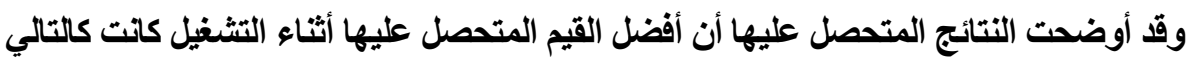

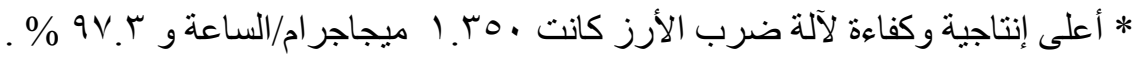

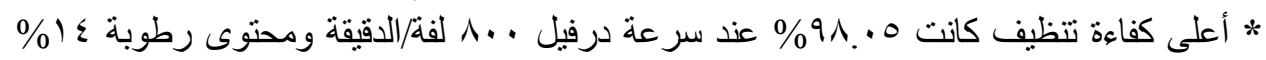

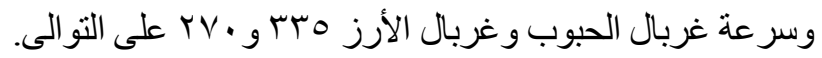

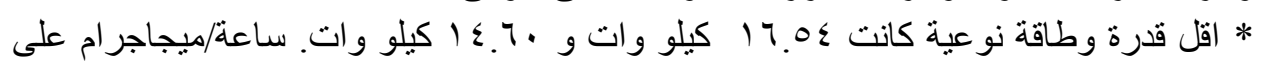
الترتيب.

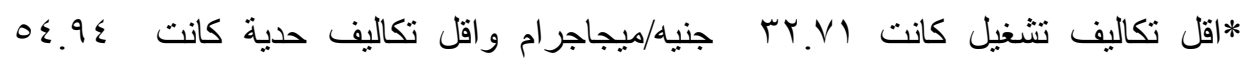

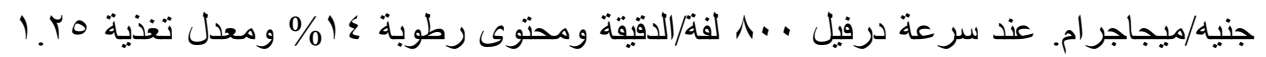
ميجاجر ام/الساعة. 